\title{
東京における昭和初期木造アパートの建築的特徵に関する研究 CHARACTERISTICS OF RENTAL WOODEN MULTIPLE DWELLINGS IN TOKYO IN THE EARLY SHOWA ERA
}

\author{
朴 炳 順*, 松 村秀一** \\ Byungsoon PARK and Shuichi MATSUMURA.
}

\begin{abstract}
To clarify the characteristics of Rental Wooden Multiple Dwellings (RWMD) in the early Showa era, 7 buildings of the present RWMD built in the first half of 1930 s were investigated. The characteristics specified from this investigation are as follows; 1) the design of exterior appearance and main entrance is semi-European style-Types, 2) the dwelling units are located at the both side of indoor corridor, 3) the manager who habitually resides plays an important role in the management of RWMD, 4) the size of dwelling unit for rent is six or four half-Tatami mats, 5) a gas range and closet are furnished for exclusive use, and a washroom, toilet, and kitchen are for common use.
\end{abstract}

Keywords : The Early Showa Era, Rental Wooden Multiple Dwellings, Exterior Appearance of Semi-European Style-Types, Plan of Double-loaded Corridor, Dwelling Uint with Gas Range, Habitual Manager 昭和初期, 未造アパート, 和洋折禹の外観, 中廊下型平面, ガス台付の住戸，常住する管理人

1. はじめに

\section{1 研究の背景と目的}

日本の都市部における居住形態として「2 階建て民営木造アパー ト」がある.この木造アパートは戦後特に 1950 年代半ばから大阪及 び東京において急増した日本独特の都市居住形態である. 欧米に普 及している集合住宅とは異なって日本における伝統的な構造である 木造であり，ほとんど 2 階建てで，民間によって建設・経営される 借家である. 更に, 居住室 (各貸室) は専用であるが洗面所, 炊事 場，便所などの一部または全部の設備を居住者同士で共用する居住 形態である. 一時宿泊施設もしくは寄宿舎ではなく「住宅」として の役割を果たしており, 昭和 28 年住宅統計調査から貸室 1 戸が「1 戸の住宅」として集計されている.このような設備共用の木造アパ 一トは戦後のみならず戦前から都市部に供給されており，僅かでは あるが現存するものもある. なお，昭和初期の木造アパートは当時 の都市への急激な人口増に対応して供給されたものであり, 戦後東 京及び大阪等の大都市における木造アパートの急増の背景と同様で ある。”戦前に建築された木造アパートは, 戦後の設備を共有しなが ら専用の居室で生活を営むという居住形態の木造アパートにつなが る前の段階として重要な時期のものである. 1980 年代からは設備専 用の木造アパートも多く供給されるがこれは設備共用の木造アパー
トの発展したものである

本研究では東京における戦前建築の木造アパートの建築的特徴 を把握するため, 昭和 10 年代に東京市内において建築された木造ア パートの実例調査及び経営者と管理人に対するヒアリングを行い, 分析結果から昭和初期木造アパートの建築的特徴を明らかにするこ とを目的とする.

\section{2 既往研究と本研究の位置づけ}

戦前のアパートに関する文献は，「共同住宅及ビルディングに関 する調査」(注 1)，「アパートメントハウスに関する調查」(注2)，「アパ 一トの調べ」(注3)等がある.これらは東京市と大阪市が行った調査 報告であり，大正期及び昭和 10 年までの状況が分かる資料である. 「都市集住様式の歴史的研究」(注 4) と「都市集住様式の歷史的研究 II」(注5) が挙げられるが，後者は「アパートメントハウスに関する 調査」の追跡調查報告であり，昭和初期の木造アパートに関する文 献として数少ない文献である. 木造アパートの構法に関する文献で はないが,「木造戸建て住宅における構法の変遷に関する研究一昭和 20 年代を通じてー」 ${ }^{\text {(注6) }}$ がある. また戦後行った調査結果が雑誌建 築技術（1955 年）に報告されている. 古川修の一連の報告には「庶 民住宅の軸部材」,「庶民住宅における布基礎」，「庶民住宅における
* 東京大学大学院工学系研究科建築学専攻 外国人客貝研究員・博士 (工学)

** 東京大学大学院工学系研究科建築学専攻 助教授. 工博
Foreign Researcher, Dept. of Arch., Graduate School of Eng., Univ. of Tokyo, Dr. Eng.

Assoc. Prof., Dept. of Arch., Graduate School of Eng., Univ. of Tokyo, Dr. Eng. 
屋根の種類」がある。「市街地建築物法令」(注クは当時の木造アパー トの設計に影響を与えていると考えられる.

既往研究（文献 12 と 13）では事例収集によるアパート建て住宅 の成因及び空間構成の考察が行われているが, 本研究では建築申請 の書類に基づく各部構法の分析に重点を置いている. また, 分析対 象に寮及び下宿は含まず民間経営者によって供給された木造アパー トに限定している.

本研究の特徴は建築申請の書類に基づく分析であり, 実地調査, 経営者及び管理人に対するヒアリング，解体調査を通じて建築申請 の内容の確認を試みた点である.

\section{2. 昭和初期林造アパート数}

平成 10 年住宅土地統計調査によると, 全国の民営借家木造共同 住宅数は約 281 万戸であり，終戦前 (注8) に建築されたものは 13 千 戸である. 平成 5 年住宅統計調査では約 2 万戸であったが， 5 年間 で急減していることが分かる.

東京都の住宅総数 ${ }^{\left({ }^{(19} 9\right)}$ は約 494 万戸戸で, そのうち半数以上は借家 である. そのうち民営借家が大半を占めており，建て方別に分類す ると約 3 割は木造の共同住宅である.この民営借家木造共同住宅を 木造アパートとみなすと，木造アパート数は約 69 万戸になる.この 内戦前に建築された木造アパート数は 3 千戸（平成 5 年調査では 4 千戸) である. 即ち, 戦前に建設された木造アパートは全国に 13 千戸存在し, 東京都内に存在するのが 3 千戸で全数の約 2 割に及ぶ. 戦前の木造アパートを設備状況別に分類すると表 1 の如く設備専用 が 6 割で，設備共用が 4 割である.

表 1 東京都における戦前建築の木造アパート数(注 10)

\begin{tabular}{|c|c|c|c|}
\hline & 設㣁専用 & 設備共用 & 合計 \\
\hline \multirow{2}{*}{ 平成 5 年調查 } & $\begin{array}{c}2,300 \bar{戸} \\
(57 \%)\end{array}$ & $\begin{array}{c}1,700 \bar{戸} \\
(43 \%)\end{array}$ & $\begin{array}{c}4,000 \bar{戸} \\
(100 \%)\end{array}$ \\
\hline \multirow{2}{*}{ 平成 10 年調査 } & $1,800 \bar{戸}$ & $1,200 \bar{戸}$ & $3,000 \bar{戸}$ \\
& $(60 \%)$ & $(40 \%)$ & $(100 \%)$ \\
\hline
\end{tabular}

「アパートメントハウスに関する調查」（文献 7) と「㢣視庁管内 の『アパート』一覧表」（文献 8）による昭和初期東京市内のアパー 卜数の推移は図 1 に示したように昭和 11 年から 16 年の 5 年間に急 増している. 当時,「アパートの氾濫期」、「1日 1 軒の増加」等と言 われていた時期である. 本研究の調査対象となった 7 棟のアパート は何れもこの時期に建設されたものである.

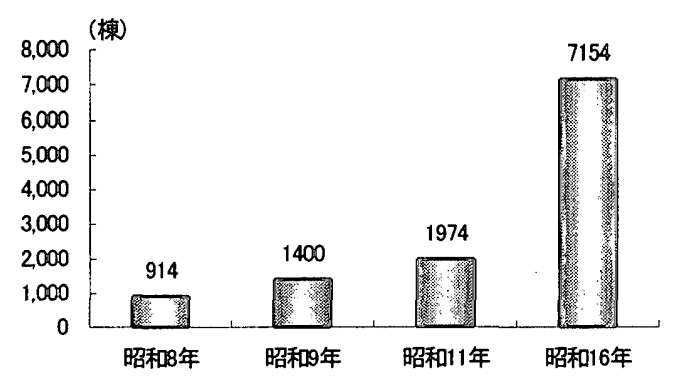

図 1 昭和初期東京市内のアパート数(注11)

\section{3. 昭和初期木造アパートの事例調查}

\section{1 調查内容}

現存する昭和初期の木造アパートの正確な数は把握できないが， 戦前に建築された木造アパートの現存数は把握できる. 東京都内に 存在する戦前に建設された木造アパート数は 3,000 戸, 1 棟当たり平 均 20 戸と想定すると約 150 棟である. しかし, 当時のアパートは 1 棟当たり貸室数が多かったことを考慮するとその棟数はもっと少な い可能性がある. 建て替えが進んでおり現存するものは重要な意味 を持ち, 現時点でこのような調査機会を逸すると木造アパートの戦 前史は把握できなくなる恐れがある.

東京市（当時）内において昭和 10 年代初期に建築された木造ア パート 7 棟 (204戸，6棟は調查当時現存）の(1)建築届もしくは建築 申請の書類及び添付図面の分析，現存する 6 棟（165 戸）のアパー トに対する(2)実測調査, (3)経営者と 5 棟のアパートの管理人 2 人に 対するヒアリング調查, (4) N 荘の解体調査を行った. 調查は 1999 年 6 月から 2000 年 10 月まで行われた. 不動産経営者によって約 60 年間経営されてきており当時としてはある程度の水準を保った木造 アパートである可能性が高いが，その数が 7 棟 204 戸に及ぶことか らその分析結果は昭和初期に建設された木造アパートの特性を示す ものと考えられる.

\section{2 建物の概要}

調査アパートの建築申請及び建築届の書類による詳細項目の内 容は表 2 にまとめる通りである，資料は経営者が保管している書類 と図面の提供によるものであり，全事例において図面が揃っている 状態ではない，事例 4 と事例 7 においては設計詳細が書かれている 書類と図面がないため, 建物の概要及び間取りは分かるが, 各部構 法の詳細については不明であるため, 各部構法分析の対象から除外 する．事例 4 に関しては残された貸室一覧表から読みとれるデータ をまとめる.

\section{(1)届出の種類}

建築申請による建物が 3 棟, 建築届よる建物が 3 棟である. 分析 に用いられた書類及び図面はすべて手書きであり，構成は手続上の 一般事項, 建築物の概要, 設計書から成る. 事例 3，6，7 において は設計変更が行われている. 申請の日付は昭和 10 年から 16 年まで であり，提出先は当時の警視総監である. 但し，事例 7 においての み所在地の警察管轄である日本堤警察長になっている.

\section{(2) 調查建物の建築時期}

調查建物は昭和 11 年 (1936) から昭和 14 年（1939）の間に建築 されたものである. 事例 7 は隅田川周辺にあったが, 調查当時唯一 現存しないものである. 建築届出時には新築が多いが, 唯一事例 6 においては改築で申請している。

\section{(3) 主要用途}

主要用途は「アパート」であり,ここでいう「アパート」とは「共 同住宅」という意味である. 昭和 13 年以降の書類においては「アパ 一ト」ではなく「共同住宅」と表記されている.

\section{(4)工事請負人}

敷地毎に異なり 4 つの敷地において 4 人の工事請負人がいる. 事 例 6 においては建築主直営となっている．設計者及び工事請負人に よって建物に個性が表れているが，建築主の意志とみられるいくつ 
の要素は共通する，例えば, 住戸の設備状況, 広い廊下, 貸室入口 扉のデザイン，押入のドアなどがそれである.

\section{(5)敷地面積}

40 坪程度から 400 坪をこえるものまである. 最も広い敷地は事例 1と 2 であり，1 棟当たり敖地面積は 228.2 坪である.「アパートメ ントハウスに関する調査」によると, 東京都内のアパートの敷地は 80 坪乃至 100 坪を利用することが最も多いと報告されていることか ら調査事例 1，2，6，7 のアパートは敷地面積が平均より大規模であ ることが分かる（表 2).

\section{(6) 工事期間}

起工及び竣工期日から分かるが，その目安は約 150 日間である. 17 日間の工事期間もみられるが, これはすでに建築中において申請 を出されたと考えられる. 事例 7 の場合は竣工が昭和 11 月の 5 月で あるが，共同住宅建築規制第 19 条による届が出されたのは昭和 16 年 3 月とかなり時間差がある.

\section{(7)構造と建築面樻}

すべて木造であり， 1 棟のみ 3 階建てがみられるが他の建物は 2 階建てである. 各階面積の合計は最も小規模の事例 3 が 42.3 坪, 最 も大規模の事例 2 は 241 坪である.

\section{3 昭和初期木造アパートの平面特性と共用設備}

設計者もしくは工事人によって平面に特徵がみられる.・調査対象 の 7 棟は異なる 5 人の設計者によるものである．事例 1 と 2 (同じ 敷地内)，3，4 と 5 (同じ敷地内)，6，7毎に異なる特徽がみられる. その特徵を表 3 にまとめる.

3.3.1 中規模以上の事例 $(1,2,4,5,6 ， 7)$ にみられる特徵 (注 12) (1) 貸室数と貸室の広さ

1 棟当たり 15 戸以上の貸室を有寸る．貸室の広さは 4 . 畳半又は 6 畳の一間が一般的である. 事例 5 において 4 畳半+3 畳, 6 盢 +3 畳 の二間，事例 6 において 6 畳半+2 畳の二間がみられるが二間の貸 室は一部に限られる，その数は 201 戸の中, 僅か 5 戸に過ぎない.

\section{(2)管理人室と事務室}

管理人室はアパートの玄関脇に設けられている．管理人室の広さ は 4 畳半が最も多くみられるが，事例 1 と 2 においては 4 胃半 +6 畳の二間である．事務室は管理人室とは別途設けられていることが ある. その広さは 3 畳又は 6 畳である. これが当時の木造アパート の特徵の一つであると言える．管理人は管理人室に常住しながら一 定の報酬をもらい; 家賃の徵収，掃除，入居者の面倒見等の仕事を

表 2 調査アパート一覧表

\begin{tabular}{|c|c|c|c|c|c|c|c|}
\hline & & & & & & & 面積単位:坪） \\
\hline 項目 & 事例1. S荘A棟 & 事例2. S荘B棟 & 事例3. T䓅 & $\begin{array}{c}\text { 事例4. } \\
\text { Hアパート本館 }\end{array}$ & $\begin{array}{c}\text { 事例5: } \\
\text { Hアパート新管 } \\
\end{array}$ & 事例6. N茫 & $\begin{array}{l}\text { 事例7. } \\
\text { Sアパート }\end{array}$ \\
\hline & 建築申請 & 建笑申請 & 建築届 & - & 建築届 & 建築申請 & 建築届 \\
\hline 1. 届出種類 & $\begin{array}{l}\text { 間取図, 平面図 } \\
\text { (昭和59年作図) }\end{array}$ & \begin{tabular}{|l} 
間取図, 土台及ひ基 \\
礎伏図, 2階梁伏図, \\
小屋組伏図, 平面図 \\
(昭和59年作図) \\
\end{tabular} & $\begin{array}{c}\text { 擁壁設計図, } \\
\text { 変更前後間取図 }\end{array}$ & 貸窒一覧表 & $\begin{array}{c}\text { 配置図，小屋梁伏図， } \\
\text { 2階床伏図，変更前平 } \\
\text { 面図，変更後平面图， } \\
\text { 断面图 }\end{array}$ & \begin{tabular}{|c} 
配置図, 姿図, 平面 \\
図, 断面图, 小屋伏 \\
図. 2階梁伏図(各々変 \\
更前後図面有)
\end{tabular} & 各階間取図 \\
\hline 2. 敷地の地名 & & 下谷区 & & & 本郷区 & & 浅草区 \\
\hline 3. 申請要旨 & & 新築 & & & 新築 & 改築 & - \\
\hline 4. 主要用途 & & アパート & & & アパート & 共同住宅 & - \\
\hline 5. 建築主 & & 本郷区弥生町 & & & 本鄕区 & 弥生町 & \\
\hline 6. 代理人 & - & - & - & & 幸一社工務所 & 坪井工務所 & - \\
\hline 7. 申早請年月日 & 昭和 1 & 年11月 & S.11.1.7 & & 昭和12年4月 & s13.8.13 & S16.3.15 (i:13) \\
\hline 8. 届け出先 & & 警視総監 & & & 警視 & 総監 & 日本堤警察長 \\
\hline 9. 敷地所有者 & & 本郷区弥生町 & & & 本郷区弥生町 & 石原 & - \\
\hline 10. 工事管理者 & & 建築主と同一人 & & & 建築主 & $=$ 同一入 & - \\
\hline 11. 設計者 & & 建築主と同一人 & & & 代理 & 里人 & - \\
\hline 12. 工事請負人 & 畔上 & 山三郎 & 雨宮王吉 & & 皆川文吉 & 建築主直常 & - \\
\hline 13. 敷地面積 & & .31坪 & 40.817 坪 & & 73.005坪 & 155.65坪 & 163.694坪 \\
\hline 14. 建築面積合計 & 228.03坪 & 330.40 坪 & 20.28坪 & 56.5坪 & 44.28坪 & 90.325 坪 (it15) $^{\text {(it) }}$ & 218 坪 (i隹16) \\
\hline $\begin{array}{l}\text { 15. 敷地面と道路面 } \\
\text { との高低 } \\
\end{array}$ & $\begin{array}{r}\text { 敷地面は道路 } \\
\text { 側而 } \\
\end{array}$ & $\begin{array}{l}\text { 面より1尺2寸低 } \\
\text { 9尺高 }\end{array}$ & 高低なし & - & $\begin{array}{c}\text { 敷地面は道路面より } \\
\text { 南1尺低北平均 } 5 \text { 寸5槀 }\end{array}$ & $\begin{array}{l}\text { 道路面よりイ)5 寸高口) } \\
\text { 高低なし八)7寸低(洼11) }\end{array}$ & - \\
\hline \begin{tabular}{|c} 
16. 起工及び \\
竣工期日 \\
\end{tabular} & $\begin{array}{r}\text { ，認可(吘可)の日 } \\
150 \text { 日闍 }\end{array}$ & $\begin{array}{l}\text { より5日後に起エし } \\
\text { にこて竣エ }\end{array}$ & $\begin{array}{l}\text { 昭和11.1.13.起工 } \\
\text { 昭和11.1.30.竣工 } \\
\end{array}$ & . & $\begin{array}{l}\text { 昭和12.4.起工 } \\
\text { 昭和12.8.31.竣工 } \\
\end{array}$ & $\begin{array}{l}\text { 許可日より1日後に起 } \\
\text { エし150日間にて竣エ }\end{array}$ & 昭和11.5. \\
\hline 17. 構造-階数 & & 木造2階建て & & 木造3階建 & 木造2 & 皆建厂 & \\
\hline 18. 各階面積合計 & 215.06 & 241 & $42.27(128.09)$ & 148 & 79.07 & 180.183 & \\
\hline 1階面積 & 107.53 & 120.5 & $20.29(66.94)$ & 56.5 & 44.28 & 90.758 & 䲞当圏面無 \\
\hline 2階面積 & 107.53 & .120 .5 & $20.2(61.15)$ & . 55 & 34.79 & 89.425 & 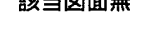 \\
\hline 3階面積 & & & & 36.5 & & & \\
\hline 19. 建築物の高さ & & 26寸 & 21.98 尺 (6.66) & & $27 尺$ & 26尺4寸 & \\
\hline
\end{tabular}


している.

(3) 玄関の檴え方

玄関は建物の他の部分に比べて立派に設けており，設計者によっ てはポーチを設けている事例もある（写真 1). 建物に組み込まれて いる場合でも構えを目立つようにしている (写真 2). 特に事例 1 は 角に玄関を設けているが，モルタル塗りにしており洋風である. そ の面積も広く取っている. 玄関に用いられた建具は事例 1 と 3 は引 き戸を，他の事例には開き戸を用いている．玄関を含む出入口は概 ね2 2 力所以上である.

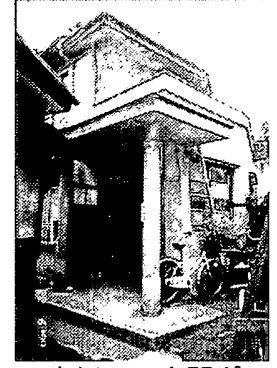

写真 1 詈例 5 の玄関ポーチ(現在)

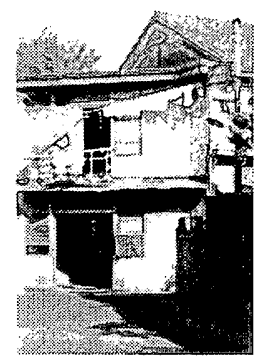

写真 2 事例 1 の玄関 (昭和初期撮影 ${ }^{(i 丶 199}$ )

\section{(4)廊下の形式}

廊下はすべて室内中廊下である，その中廊下を挟み，両側に貸室 を配置する形が一般的にみられる. 事例 1 と 2 は H 字型の中廊下を 挟み両側に貸室が並ぶ. 廊下の幅 ${ }^{(\text {注 }}{ }^{20)}$ は 6 尺 (う182 cm) で広々と している，階段は 2 個以上を室内に設けている. 1 階廊下は土足で あり，階段で履き替える場合が多い。

（5）共用設備
共同炊事場と便所は集まって配置されており，上下階同じ場所に ある. 建物の中での位置は建物の中央にある場合と建物の端にある 場合がある．事例 4 においては階段の踊り場に共同便所がある．共 同便所には小便器と大便器があり, 大便器は壁で区切られている. 現在における共同便所と同じ形式である.便所は昭和 12 年以後建築 されたアパートにおいては水洗にしている，共同炊事場においても ガス台が設置されているが，洗面所にガス台はみられない，事例 1 と 2 の洗面所は便所・炊事場とは離れ，階段の脇に位置するため開 放的な空間である.

\section{(6)貸室内専用設備の設け方}

押入はガス台の面積を確保するため, 一般的に用いられる一間 (6 尺）ではなく，幅 4.5 尺程度である. 一間の押入を区分けして 4 分 の 3 を押入に 4 分の 1 にガス台を設けている．該当する壁面全体で は，9 尺の間口を半分に分け， 4.5 尺分を押入に充て，残りの 4.5 尺 分の 3 分の 1 をガス台に 3 分の 2 を土間（入口）に割り当てた形に なっている. 従って, 設備部分は必ず土間の隣, 即ち廊下側に位置 する. 流しを設けている事例 5 においてはガス台部分を更に半分に 分け，それぞれガス台と流しを設けている．流しの内部は亜鉛鉄板 仕上げであった.

押入の扉は引き戸が多いが，事例 1，2，6の三つの事例において は開き戸が用いられている. 当時押入において日本の住宅に一般的 に使われた襖ではなく開き戸（ドア）を用いたのは特徵的である. 各住戸においてガス台設置に対応する換気のため, 出入口ドアの上 部に換気窓を設ける.（図 2, 図 3）

各貸室にガス台を設けており，事例 5 には流し台まで設けられて いて当時としては良好な設備であったことが分かる.「アパートの調 べ：大阪市社会部調查課，昭和 6 年 4 月」に「…各戸に炊事場を設

表 3 調查アパートの平面特性

\begin{tabular}{|c|c|c|c|c|c|c|c|c|c|}
\hline \multicolumn{3}{|c|}{ 項目 } & 事例1. S荘A亪 & 事例2. S荘B竄 & 事例3. T荘 & $\begin{array}{c}\text { 事例4. } \\
\text { Hアパート本館 }\end{array}$ & $\begin{array}{c}\text { 事例5. } \\
\text { Hアパート新館 }\end{array}$ & 事例6. N葑 & 事例7. Sアパート \\
\hline \multicolumn{3}{|c|}{ 1. 現存 } & 現存 & 現存 & 現存(改筑) & 現存 & 現存 & 現存(調査当時) & 無 (建替) \\
\hline \multicolumn{3}{|c|}{ 2. 玄関 } & 土間 & 土間 & 土間 & 土間 & ポーチ・土間 & ポーチ・土間 & ポーチ・土間 \\
\hline \multicolumn{3}{|c|}{ 3. 非常口数 } & 3 & 3 & 0 & 1 & 1 & 2 & 4 \\
\hline \multicolumn{3}{|c|}{ 4. 廊下形式 } & 中廊下(H字型) & 中廊下(H字型) & 室内片廊下 & 中廊下 (I字型) & 中㰾下(T字型) & 中廊下 (I字型) & 中廊下 (コの字型) \\
\hline \multirow{9}{*}{$\begin{array}{l}5 . \\
\text { 贷 } \\
\text { 公 } \\
\text { 数 } \\
\text { 及 } \\
\text { ひ } \\
\text { 面 } \\
\text { 積 }\end{array}$} & \multirow{3}{*}{ 1階 } & 6㽬 & 10 & 13 & 3 & 10 & 1 & 7 & 13 \\
\hline & & 4畳半 & 7 & 9 & 1 & - & 4 & 9 & 5 \\
\hline & & その他 & - & - & - & - & 2(4置半+3異) & 1(4疊半＋2置) & - \\
\hline & \multirow{3}{*}{ 2階 } & 6罝 & 10 & 13 & 3 & 7 & 3 & 7 & 11 \\
\hline & & 4置半 & 8 & 9 & 1 & - & 4 & 11 & 10 \\
\hline & & その他 & - & - & - & 2(8畳) & 1(6畳＋3燢) & 1(6畳+2囬) & - \\
\hline & \multirow{2}{*}{ 3階 } & 4员半 & - & - & - & 6 & 二 & - & - \\
\hline & & その他 & - & - & - & 2(4畳半弱) & - & - & - \\
\hline & & 計 & 35 & 44 & 8 & 27 & 15 & 36 & 39 \\
\hline \multirow{2}{*}{\multicolumn{3}{|c|}{$\begin{array}{l}\text { 6. 管理人室の有無と } \\
\text { 面䅡 } \\
\end{array}$}} & 有 & 有 & \multirow{2}{*}{ 無 } & 有 & 有 & 有 & 有 \\
\hline & & & 4罟半+6査 & 4畳半+6畳 & & 4冨半 & 4罝半 & 4畳半 & 4置半 \\
\hline \multirow{2}{*}{\multicolumn{3}{|c|}{$\begin{array}{l}\text { 7. 毫務室の有無と } \\
\text { 面檟 }\end{array}$}} & 有 & 有 & \multirow{2}{*}{ 無 } & 有 & 有 & \multirow{2}{*}{ 無 } & 有 \\
\hline & & & 6圕 & 6畳 & & 3㽬 & 3盢 & & 6置 \\
\hline \multirow{6}{*}{$\begin{array}{l}8 . \\
\text { 設 } \\
\text { 備 } \\
\text { 状 } \\
\text { 況 }\end{array}$} & \multirow{3}{*}{ 専用 } & 押入 & 0 & 0 & 0 & 0 & 0 & 0 & 0 \\
\hline & & ガス台 & 0 & 0 & $x$ & 0 & $\mathrm{O}$ & 0 & 0 \\
\hline & & 流し台 & $x$ & $x$ & $x$ & $x$ & $\mathrm{O}$ & $x$ & $x$ \\
\hline & \multirow{3}{*}{ 共用 } & 炊事場 & 0 & 0 & 0 & 0 & 0 & 0 & \\
\hline & & 洗面所 & 0 & 0 & $x$ & 0 & $x$ & 0 & 0 \\
\hline & & 便所 & $\mathrm{O}$ & 0 & 0 & 0 & 0 & 0 & 0 \\
\hline \multicolumn{3}{|c|}{ 9. 陵段数 } & 4 & 4 & 1 & 2 & 2 & $2+$ 非常階段 2 & 2+非常階段 1 \\
\hline
\end{tabular}


けているところは 1 ヶ所である. 東京のアパートが 1 戸ごとに炊事 場を持っているに反して，大阪のアパートが炊事場を持たないのは 本市におけるアパートの一特徴と言ってもよい.」との記述から調査 事例のみではなく当時東京における木造アパート設備は少なくても 各貸室に炊事場即ちガス台が設けられていたことが分かる.

(7)貸室(住戸ユニット)

調査建物の貸室住戸は 4 畳半又は 6 畳の畳敷きと押入，ガス台， 半間の土間で構成される. 住戸の大きさは 4 畳半が $9 \times 12$ 尺(う273

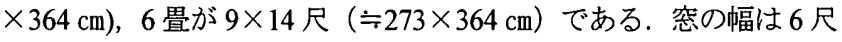
$(\fallingdotseq 181.8 \mathrm{~cm})$ であり, 引き空が多く用いられ，すべての住戸に設け られている

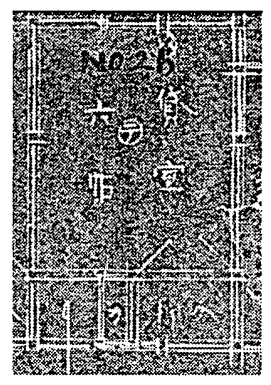

図 2 流し台のない住戸(事例 6).

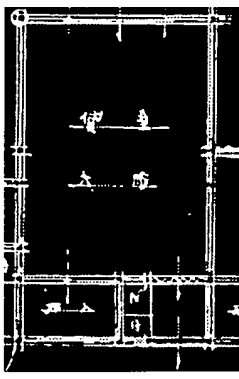

図 3 流し台のある住戸 (事例 5, N: 流L, G:ガス台)

\subsection{2 小規模の事例(3)にみられる特徵}

調査事例の中では唯一全ての面において異なる形式である事例 3 は既存の大規模アパートの隣地に増築したため，全貸室数が 8 戸と 小規模である. 平面も室内片廊下型と特殊であり, 棟内に管理人室 を設けていない．しかし，当時既存のアパートに管理人がいたこと から全事例に管理人室が見られることになる. 玄関と階段が一つし かなく,設備においても各貸室内にガス台を設けず共同炊事である.

\section{4 各部構法の特徵}

各部構法の分析において, 事例 3, 事例 4, 事例 7 につては書類 不備のため分析の対象から外す. 対象とした 4 事例の各部構法の特 徵を表 4 にまとめる.

\section{(1) 外観}

特に記入されていない事例もあるが，洋風が加味されている場合 は和洋折衷式又は和洋風と記入されている. 今回の対象では和風よ りは和洋折哀の外観が多く見られる。

\section{(2)内外壁と天井 ${ }^{(\text {(氵21) }}$}

外壁の仕上げとしてトタン張り一部モルタル仕上げ，モルタル塗 り人造洗い出し及びリシン仕上げ, 生子. ${ }^{(22)}$ 板張り, ラスモルタル 塗り，南京下見板張りがみられる.内壁は真壁及び漆喰塗りで, 一 部大壁を用いた事例もある. 大壁には腰羽目板張りとし間仕切り壁 及び障子引き戸，扉等の建具を建て込む.

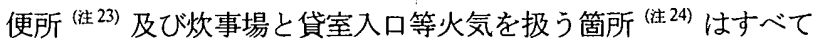
木摺り打ち鉄網張りセメントモルタル厚 8 分塗りにしている. 1 階 及び階段裹は鉄網張り厚 6 分セメントモルタル塗りとし， 2 階天井 は和式竿縁天井, “漆喰塗り及び板天井がみられる.

(3)㾀根と小屋組
屋根 ${ }^{(\text {注 } 25)}$ の形状は寄棟, 切妻, 玄関等の一部に陸屋根と片流れが みられる，申請の書類には「方形」と記入している例もあるが，小 屋梁図から寄棟と判明した，屋根勾配は切妻，奇棟において 5 寸, 片流れにて 3 寸，陸屋根にて1 寸から 2 寸の勾配を取っている. 仕 上げ材は古瓦, 引掛け栈瓦, スレート, 便利瓦, 浅堅スレート, 亜 鉛引き鉄板营きがみられる。

陸屋根はアスファルトルーフィングを敷き，便利瓦を数枚張り， 上は豆砂利敷きモルタル厚 1 寸 5 分塗りとする．又は陸屋根アアス ファルトルーフィングを交互 3 面施工した後鉄網張りモルタル 1 寸 2 分塗りにしている.

和式小屋組を用い，小屋梁には末口 4 寸または 5 寸の丸太を用い る. 棟木，母屋，束には杉 3 寸又は 3.5 寸，二重梁には末口 4 寸の 丸太，隅木 3 寸角を垂木には松 2 寸角を用いる.

\section{（4）基礎と土台及び軸部(注26)}

基礎に最もよく使われたのはコンクリート布基礎である. 周囲を 布堀, 割栗石を敷き詰めて巾 5 寸厚 8 寸の布コンクリートを打つ. 9 尺間に径 5 分ボルトを埋め込み土台と締め付ける．束柱下は暑堀, 栗石をつき固めた後コンクリートを打つ. $\mathrm{T}$ 荘においては布基礎で はなく，割栗石を敷き，柱の下に土台石を敷く方法を用いた。

昭和 30 年「建築技術」 6 月号にて古川修は「庶民住宅における布 基礎」について報告している．借家における布コンクリート基礎の 普及時期のピークを昭和初期と報告している．調査事例の建築時期 も昭和初期であり，この記述とも整合する結果となっている.

土台に用いた樹種 ${ }^{(2)}$ 27) は赤松が最も多く, 杉は 1 事例みられるだ けである. $3.5 \times 3.5$ 寸または $4 \times 4$ 寸の角材を用いている. 火打土台 も 4 事例においてみられる．杉 3 寸角または 4 寸角が使用されてい た.

通し柱には杉 4 寸角又は 4.5 寸角が使用され，管柱は 2 階よりは 1 階で，内側よりは外側で太い材木が用いられる。しかし，すべての 管柱に同じ太さの材木を使っている場合もある．杉 3 寸 3 分から 4 寸までの角材が用いられている. 胴差には松 4.5 寸が, 間柱には松 2 寸角が使用されている．筋違の記入は 2 事例からみられ，杉 4 寸が 用いられる.

土台，柱等の木部が直接石またはコンクリートに接する部分は防 腐材を塗る処置を行う. 土台と柱の接合は埋め込みボルトで締め付 けている.

\section{(5) 床構造}

束，大引を杉 3 寸または 3.5 寸角に，根太を松 2 寸または松 4 寸 角にしている．床板は松 6 分板または杉を用いている． 2 階床梁に は松 4 寸 7 分角材を, 火打梁には杉 3 寸または 3.5 寸角を, 床根太 には杉 4 寸角を用いる.

各柱梁などの接合は短冊鉄物または羽子板ボルト締めとしてい る. 居室の木造床構造は地盤面より 1 尺 5 寸以上である. 貸室内床 は畳敷き，一部板張りである.

1 階廊下はコンクリート吒き仕上げ，2 階廊下は縁子板張りであ

る. $\mathrm{H}$ アパート新館においては 2 階の廊下もコンクリート叨きにし ている.

\section{（6）付属設備}

雨樋は亜鈆製を用いる．排水溝は土管を使用し，継ぎ手はセメン トモルタルを使用し接合する。下水溝はコンクリート造りまたは. 


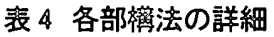

\begin{tabular}{|c|c|c|c|c|c|c|}
\hline \multicolumn{3}{|c|}{ 項目 } & 拿例1. S荘A榢 & 寒例2. S䓅B楾 & 害例5. Hアパート新館 & 亨例6. N萡 \\
\hline \multicolumn{3}{|c|}{ 1. 外钼 } & \multicolumn{2}{|c|}{ - } & 和洋折衰式 & 和洋風 \\
\hline \multirow{2}{*}{ 2. 壁 } & \multicolumn{2}{|c|}{ 外壁 } & \multicolumn{2}{|c|}{ トタン張りー部モルタル } & $\begin{array}{l}\text { モルタル䤠り人造洗い出し及 } \\
\text { びリシン仕上げ, 生子板張り }\end{array}$ & ラスモルタル・下見板报 \\
\hline & \multicolumn{2}{|c|}{ 内壁 } & \multicolumn{2}{|c|}{ 真壁 } & $\begin{array}{c}\text { 貝壁塗り及び滚喰塗り } \\
\text { 大壁腰羽目板張り }\end{array}$ & 真壁，一部大壁 \\
\hline \multirow{4}{*}{ 3. 床 } & \multicolumn{2}{|c|}{ 翼室 } & \multicolumn{2}{|c|}{ 骨 } & 荁·板の間 & 量 \\
\hline & \multirow{2}{*}{\multicolumn{2}{|c|}{ 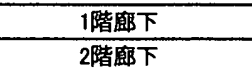 }} & \multicolumn{2}{|c|}{ コンクリート叨き } & \multirow{2}{*}{ コンクリート叨き } & コンクリート \\
\hline & & & 板割張り（杉） & 板割張り & & 緑子板張り \\
\hline & \multicolumn{2}{|c|}{ 便所·㰠專場·贷室入口 } & \multicolumn{2}{|c|}{ セボントモルタル厚さ8分症り } & - & - \\
\hline \multirow{2}{*}{ 4. 天井 } & \multicolumn{2}{|c|}{1 階·階段变 } & \multicolumn{2}{|c|}{ セメントモルタル } & セメ゙ントモルタル & モルタル \\
\hline & \multicolumn{2}{|c|}{2 陵 } & \multicolumn{2}{|c|}{ 和式竿緑 } & 漆喰漥り及び板天井 & $\begin{array}{c}- \\
-\end{array}$ \\
\hline \multirow{3}{*}{ 5. 屋根 } & & & 方形. & 陸屋根 & 方形・片流れ & 切华，玄関陸屋根 \\
\hline & & & 本家屋屋根勾酉 & ，陸屋根勾配1寸 & 方形5寸, 片流れ3寸 & 切要5寸, 陸屋根2寸 \\
\hline & & & 本家古瓦，陸屋根便利瓦 & 本家スレート，睦屋根便利瓦 & 引掛镂瓦, 垔鉛引鉄板暻 & 引掛栈瓦，陸屋根 \\
\hline & & & 割石十布 & 引リート打ち & 割栗石＋布コンクリート打ち & 布堀 \\
\hline & & & & 寸角 & 赤松 4寸角 & 檜 4 寸角 \\
\hline & & & & 5 分 & 杉了寸角 & 杉了角 \\
\hline & & & 4捔 & 4 寸 5分 & 杉 4 寸角 & 杉 4 寸角 \\
\hline & 1䧊管妵 & 外側 & & & 款 3 寸 6 分 & \\
\hline 6. 款部 & & 内側 & 3寸6分角 & 3寸 5 分角 & 视 3 寸 6 分 & 榇3寸6分角 \\
\hline & 2 階管柱 & 外側 & 杉3寸3分角 & 杉3寸8分 & 杉 3 寸 4 分 & - \\
\hline & & 内側 & 3寸3分角 & 3 寸 6 分角 & - & 讼4寸5分角 \\
\hline & & & 松 & 5 分 & 一 & $\frac{\text { 松 } 4 \text { 寸 } 5 \text { 分角 }}{-}$ \\
\hline & & & & & $\frac{A=218}{-}$ & - \\
\hline & & & 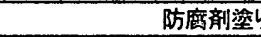 & に込みボルト & 防腐材凃 & 防糜剤筀 \\
\hline & & & 杉3 & 5分角 & 杉了角 & 杉了角 \\
\hline & 相大 & 1 階 & & & 松 2寸角 & 松2寸角 \\
\hline & 很太 & 2 階 & & & 松 4寸角敨居木 & 松 4 寸角 \\
\hline 7. 床橔造 & & & & & 板割張り & 杉 \\
\hline & & & & & & 昖 4寸7分角 \\
\hline & & & & 分角 & 杉了寸角 & - \\
\hline & & & & & 杉 4 寸角 & - \\
\hline & & & & 屋組 & - & 和小屋 \\
\hline & & & & & - & - \\
\hline & & & 往間距離 9 尺:森口 4 & 主間距離 12 尺:表口 5 寸 & - & 松丸太，柰口 4寸 \\
\hline 8 小展掊焝 & 棟不 & & 杉3寸5分有 & 電梁态口 4 寸 & 颙了寸角 & 杉3寸角 \\
\hline 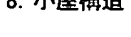 & & & & & & 杉6貫 \\
\hline & & & & & & 松 2 寸角 \\
\hline & & & & & 松2寸角 & - \\
\hline & & & & & 5寸間に板張り & - \\
\hline 9. 居室の木i & & & & 以上 & 1尺5 寸以上 & 1尺5 寸以上 \\
\hline 10. 居室の天 & & & & & 7 尺以上 & 7尺2寸以上 \\
\hline & & & $10.3 / 4$ & $.65 / 4 / 4$ & $9.3 / 3.5 / 7.1 / 6.64 / 4 / 4$ & $10 / 4 / 8.6 / 5.9 / 9 / 4.5$ \\
\hline 1) 陡的 & & & $10.3 / 4$ & $0.65 / 4 / 4$ & $9.3 / 3 / 6.9 / 6.6 / 4 / 4$ & $10 / 4 / 8.6 / 5.9 / 9 / 4.5$ \\
\hline 11. 咜段 & & & & & - & $10.2 / 2.6 / 5 / 7.3 / 5.6 / 5$ \\
\hline & & & $10.3 / 2.5 / 0.6 /$ & $2.5 / 2.5$ (2 力所) & - & $5.1 / 2 / 5 / 7.3 / 2.5 / 2.5$ \\
\hline 12. 便所榴造 & & & & & 水洗式便所 & 水洗式放流便所 \\
\hline 13. 井戸と汲 & 更所活物溜 & 酋離 & 周囲距離 18 & 〈内に井戸なし & - & 18 尺以内に井戸なし \\
\hline
\end{tabular}

土管を埋設する. 継ぎ手の接合は排水溝と同じである. 消化器を 1 , 2 階共に配置し, 避難用の縄を 2 階に必ず設置する

\section{4. まとめ}

戦前に建築された木造アパートの建築的特徴を把握するために, 昭和 10 年代に建築された 7 棟の木造アパートの実態調査を行った. 建築当時の建築申請書類及び図面の分析の結果, 平面構成の特徵, 外観及び各部構法の特徵, 設備状況等が把握できた. なお，2000年 10 月に実施された $\mathrm{N}$ 荘の解体工事によって図面と書類に記入され ている事項が実物とほぼ一致していることを確認しており, 建築申 請の仕様通り建築されたことが分かる. また, 市街地建築物法令（注
28) の内容は木造アパート設計の段階で多く参考にされていたことが 分かる.

調査木造アパートの建築時期は昭和 10 年代前半 (1930 年代後半) である.この時期は当時「アパートの汇濫期」といわれた時期であ り，木造アパートが急増した時期に当たる.

調査アパートから明らかになった昭和初期木造アパートの建築 的特微として，1）室内廊下の両側に貸室が配置される．2）玄関の 構え方に重点を置き，外観は和風と和洋折哀もみられる．3）管理人 室及び事務室を設けており，アパートに常住する管理人は当時アパ 一ト経営において重要な役割を果たしていた，4）貸室（住戸）は4 畳半または 6 畳一間が基本であり，二間のものは非常に少ない，5） 
専用の設備は押入とガス台があり，流し台を設けるケースもみられ る. 共用の設備には炊事場, 洗面所, 便所があり, 浴室はみられな い,ことが明らかになった。

本論文は参考文献 20，21 を修正，加筆したものである. なお，本 研究のために建築申請の書類及び図面の御提供と実測調査に御協力 いただいた踏谷鉦吉氏に心よりお礼申し上げる次第である.

\section{参考文献}

1) 総理府統計局: 昭和 28 年 住宅統計調查結果報告, pp.1 2, 1954.

2) 総務庁統計局 : 平成 10 年 住宅土地統計調查結果報告 第 1 巻 全

国編，pp.20 22，2000.8

3) 総務庁統計局 : 平成 10 年 住宅土地統計調查結果報告 第 5 巻 都 道府県編 その 13 東京都, pp.92 93，2000.6

4) 総務庁統計局: 平成 5 年 住宅統計調查結果報告 第 1 巻 全国編, pp.20 27, 1995.8

5)東京都住宅局: 平成 5 年 住宅統計調査 東京都特別集計 統計表, pp.400 401，1996.3

6) 東京都住宅局: 平成 10 年 住宅土地統計調查 東京都特別集計 $C D$, 2001.

7) 東京府社会課 : アパートメントハウスに関する調査, pp.9〜 18, 1936.4

8）警視庁 : 警視庁管内のアパート一覧表, 1936.7

9）市街地建築物法，大正 8 年（昭和 9 年，昭和 13 年改正)

10）東京市社会局：共同住宅及ビルディングに関する調查，大正 12 年

11）大阪市社会部：アパートの調べ，昭和 6 年

12）東京都立大学石井研究室, 東洋大学前田研究室 : 都市集住様式の歴 史的研究, 新住宅普及会住宅建築研究所, 1974. 9

13）東京都立大学石井研究室, 東洋大学前田研究室: 都市集住様式の歴 史的研究 II，新住宅普及会住宅建築研究所，1975.9

14）古川修：庶民住宅の軸部材，建築技術 pp35～38，1955.5

15）古川修：庶民住宅におけ方布基礎，建築技術 pp45～47，1955.6

16）古川修: 庶民住宅における屋根の種類, 建築技術 pp26 28, 1955.9

17）井上朝雄 : 木造戸建て住宅における構法の変遷に関する研究一昭和

20 年代を通じて一，東京大学修士論文，2000.1

18）坂本功監修: 日本の木造住宅の 100 年, 日本木造住宅産業協会, 2001.3

19）朴炳順 : 東京における木造アパートの発生及び建筑的特徴に関する 研究, 東京大学学位論文, 2000.6

20）朴炳順，松村秀一：初期木造アパートの発生と建築的特徵に関する 研究，日本建築学会大会学術講演概要集，2000.9

21）朴炳順，松村秀一：木造了パートの建築的特徵の变遷に関する研究 その 1 昭和 10 年代に建築された木造アパートを中心に, 2000 年度 日本建築学会関東支部研究報告集, 2001.3

注 1）文献 10）上野俱楽部, 佐藤別館, 三笠はウス, 芸術クラブ, 桜楓 会アパートメントハウス，新宿アパートメントハウス，“細民屈の共 同住宅を紹介している.

注 2）文献 7）東京市 35 区におけるアパートメントハウス 1105 棟の実 態について調查. 但し, 1 棟当たり 10 室以上のもの, 昭和 10 年 5 月調查. 昭和 11 年 1351 棟, 木造 1037 棟, 鉄筋コンクリート造 159 棟 (そのうち 85 棟は同潤会), 木筋コンクリート造 3 棟.

注 3）文献 11）大阪市における 24 棟のアパートに関する調査報告.

注 4）文献 12）東京における木造アパートの発達 明治期及び大正期の 木造アパートについて述べている

注 5）文献 13)「アパートメントハウスに関する調查」の追跡調查を 1974 年から 1975 年まで行った．実地調查を行ったアパートは 8 例, 昭 和 10 年以降に建築されたものが 2 例である. 建築時期は大正 6 年 から昭和 20 年までである.

注 6) 文献 17)

注 7) 文献9）大正 8 年 4 月 4 日法律第 27 . 号（昭和 9 年 4 月 6 日法律第 16 号一部改正，昭和 13 年 3 月 26 日法律第 29 号一部改正)

注 8）住宅・土地統計調查では終戦前と分類しているが，本報告では「戦 前」と表記する.

注 9). 住宅の所有の関係『不詳」を含む。

注 10）出典：文献 4)。ここでいう「設備専用」,「設備共用」とは住宅・ 土地統計調查上, 次のように分類される.「設備専用」とは台所及 び便所の両方が専用である場合，「設備共用」とは台所及び便所の うち、いずれか一方あるいは両方が共用の場合である，なお，戦前
に建築されたアパートにおいては浴室まで専用であるものは極め て少ないと考えた方が正しい

注 11）資料 : 昭和 8 年から 11 年のデータは警視庁調ベ「警視庁管内ア パート一覧表」文献 8).

注 12）東京における昭和初期木造アパートに関する既往文献には文献 12 と 13 がある.これは文献 7 の追跡調查を 1974 年から 1975 年ま で行ったものである．実地調查を行ったアパートは 8 例（建築時 期は大正 6 年から昭和 20 年までである）で，昭和 10 年以降に建 築されたものが 2 例である．東京を中心に形成されたアパート建 て住宅の成因に着目し，ほとんど残っていない往時のアパート建 築について事例を収集し，空間構成を考察することを目的として いる．事例のうち，本研究の調査対象と類似する 4 事例について 見てみると，管理人室を設けているのが 3 事例，玄関にポーチを 設けているのが 2 事例; 階段で履き替えるのは 3 事例みられる. 共用設備は炊事場以外に洗濯場を設けているのが特徴的である. 専用設備は台所を設けている住戸とない住戸が混在する. 4.5 畳を 基本とする住戸が 3 事例見られる.

注 13）䇋工期日は昭和 11 年 5 月であるが申請はその 5 年後に出してい る.

注 14）書類に記入されてある通りであるが 1 階床面積などと照らし合わ せて考えると数字が大幅に違うことが分かる。

注 15）設計変更によって 90.758 坪になる。

注 16）1 1 階床面積 109.25 坪，2 階床面積 108.75 坪である.

注 17） 1）正面の北側，口）正面の中央部分，八）正面の南側を指す.

注 18）前願においてはS.12.1.起工S.12.4.30.竣工である.

注 19）経営者の提供によるものである.

注 20）文献 9）特殊建築物規則，第三共同住宅，第 33 條住戸又八住室 ノ床面積ノ合計百平方メートル以上ノ階二設クル常用ノ共用廊下 八左ノ規定二依ルベシ。一，廊下ノ有効幅員八片廊下二在りテハ 1.2 メートル以上中廊下二在リテハ 1.5 メートル以上卜為スコト.

注 21）文献 9）特殊建築物規則，第三共同住宅，第 19 條左ノ各号ノ一 二該当スル共同住宅ノ建物八其ノ主要ナル壁体，床，柱，屋根及 階段习耐火構造卜為スベシ。一，建物ノ第二階二於テ共同住宅ノ 用二供スル部分ノ床面積六百平方メートルヨ超ユルモノ。，建 物ノ第三階以上ノ階二住戸又八住室习設クルモノ。

注 22）波形をした板の通称，ふつう屋根や塀に用いる波形の亜鉛引鉄板 や波形の石綿スレート板などをいう.

注 23）文献 9）特殊建築物規則，第三共同住宅，第 29 條共用ノ便所八 左ノ規定二依ルベシ.一, 外気二面シ開放シ得ル空习設ケルコト. 二，床及床面ヨリ十七ンチメートル迄ノ部分ノ周壁八不浸透質， 材料ヨ以テ構成又八被覆スルコト.

注 24）文献 9）特殊建築物規則，第三共同住宅，第 27 條 共同住宅二 於テ常時火気 7 使用スル箇所二八防火上適当ナル設備ヨ為スベシ.

注 25）文献 16）に次のように報告している，昭和 25 年建設省住宅局 都市住宅調査結果によると粘土瓦が約 6 割, トタン金属板が約 2 割を占めている. 和瓦の普及時期を明治 35 年以前, トタンの普及 時期を大正 5 年から 15 年の間と報告している. また, 全国都市の 9 割以上が 4.5 寸万至 5 寸の屋根勾配を支配的なものとしている.

注 26）文献 9）施行規則，第二木構造及木骨構造，第 48 條 柱，梁そ ノ他之二類スル構材ノ継手及仕ロニシテ主要ナルモノ八「ボール 卜」締其/他ノ適当ナル方法二依紧著スーシ. 第 49 條建物ノ 主要ナル柱八堀立卜為スヘカラス但シ適当ナル防腐方法习施シタ ルモノ八此ノ限二在ラス. 第 50 條 堀立二非サル柱ノ下部二八土 台又八脚固习使用スヘシ但シ柱ヨ其ノ基礎二緊著シタルトキハ此 八限二在ラス。第 51 條 石, 棟瓦其/他ノ腰積习有スル建物八之 ヨ土台敷構造卜為シ士台八腰積二緊結スヘシ。

注 27）文献 14）によると，土台の材種について檜を慣用している都市 が最も多いと報告している．また庶民住宅の柱材としてほとんど 杉を使用している都市が全都市の約 8 割であり，柱径の寸法は 3.5 寸を慣用していることが明らかになったと報告している．但しこ の調查は 1954 年に行ったものである。

注 28）文献 18）で大橋好光は「物法施行規則の構造規定は，多くの条 項が大正 7 年の警視庁の建築取締規則案を踏襲していた」と指摘 している.

（2001年 5 月 10 日原稿受理，2001年11月 8 日採用決定） 